\title{
USE OF THE DYNAMIC MODEL FOR THE ASSESSMENT OF WINTER CHILLING IN A TEMPERATE AND A SUBTROPICAL CLIMATIC ZONE OF CHILE
}

\author{
Francisco J. Pérez ${ }^{1 *}$, Juan Ormeño N. ${ }^{2 *}$, Bryan Reynaert ${ }^{1}$, and Sebastián Rubio ${ }^{1}$
}

\begin{abstract}
A B S T R A C T
Accumulated chilling was estimated by applying three different models to the hourly autumn-winter temperature records from Santiago $\left(33^{\circ} 34 \mathrm{~S}\right.$ lat; 625 m.a.s.1.) and Vicuña $\left(30^{\circ} 02^{\prime} \mathrm{S}\right.$ lat; 643 m.a.s.1.) for the years 2005 and 2006. The model of chilling hours, currently used in Chile as an agroclimatic indicator, was of limited use for effectively contrasting a subtropical condition (Vicuña) with a temperate area such as Santiago. The application of the Utah model gave negative values from March to May, and even up to June in Vicuña, since in this model the chilling effect is "negated" by warmer temperatures. However, a modified version of the Utah model named Positive Chilling Units (PCU), in which negative values are omitted, showed differences in the accumulated chilling between both regions, although these differences were of small magnitude and were noted only from July onwards. The Dynamic Model, which considers that chilling is irreversibly accumulated as quantum or Chill Portions (CP), showed that chilling in Santiago doubled that of Vicuña, and that these differences in location were already expressed at the beginning of autumn, confirming, thus, the suitability of the model for subtropical conditions. In this work the advantages of the dynamic model over other models are discussed.
\end{abstract}

Key words: accumulated winter-chill, bud dormancy, dynamic model.

\section{INTRODUCTION}

It has been argued that winter chill is a necessary factor for deciduous fruits in temperate climates so that latent buds can break the state of winter recess or endodormancy (ED) and begin growing during the spring (Saure, 1985; Lang, 1987). In regions with temperate climates, the cold requirements of the buds of deciduous fruits are satisfied during the winter period and bud-break occurs in the normal way at the beginning of spring. However, in sub-tropical agricultural conditions, the lack of winter cold causes an erratic and uneven breaking of buds, with the consequent reduction in the quantity and quality of the fruit (Lang, 1987; Allan and Burnett, 1995).

This phenomenon is observed in Chile particularly in table grapes (Vitis vinifera L.) in the regions of Atacama and Coquimbo, given that to produce commercially, growers must apply hydrogen cyanide in order to compensate for the lack of winter cold (Reginato et al., 1994). In this region, as in other subtropical areas, the lack of winter cold constitutes a limiting factor for the cultivation of other deciduous fruits, such as stone fruit, and emerging from this the interest in developing varieties with low requirements of cold, adapted to sub-tropical climates (Boonprakob and Byrne, 2005).

The method to determine the cold requirements for deciduous fruits proposed by Weinberger in 1950 is based on the premise that the buds must remain a

\footnotetext{
${ }^{1}$ Universidad de Chile, Facultad de Ciencias, Casilla 653, Santiago, Chile. E-mail: frperez@uchile.cl; jormeno@inia.cl_*orresponding autor.

${ }^{2}$ Instituto de Investigaciones Agropecuarias, Centro Regional de Investigación La Platina, Casilla de Correos 439/3, Santiago, Chile Received: 27 March 2008. $\quad$ Accepted: 31 May 2008.
} 
number of hours under a critical temperature $(<7$ and $>0{ }^{\circ} \mathrm{C}$ ) during the winter season (chilling hours or $\mathrm{CH})$ to break adequately in the spring. In this way, species of low $(<500 \mathrm{CH})$ and high $(>1000 \mathrm{CH})$ chill requirements have been defined in an arbitrary manner (Tao, 2005).

This nomenclature derived from the concept of $\mathrm{CH}$ is the most commonly used in Chile, and it is supposed that only low temperatures within the defined range determine, irreversibly, accumulated winter-chill. Nevertheless, these concepts are not adjusted to experimental observations, given that there are numerous cases in the literature in which distinct chilling requirements have been reported for the same variety, depending on the locality. As an example, in the case of kiwi (Actinidia chinensis Planch.) $500 \mathrm{CH}$ has been reported as a requirement in one zone and 1000-1300 CH in another (Powell, 1997). In the case of the grapevine cv. Thompson Seedless in Chile, a range of 500 to $800 \mathrm{CH}$ has been reported for the northern zone (Rojas et al., 1999), a value of $993 \mathrm{CH}$ for the central zone (Lyon et al., 1989) and $430 \mathrm{CH}$ for the Aconcagua Valley (Sapiaín et al., 2005).

These divergences can be due to two types of factors: 1) the imprecise definition of the period in which $\mathrm{CH}$ are accumulated, and 2) the lack of consideration of the negative effect that high winter temperatures can have on the accumulation of winter cold. In relation to the first point, $\mathrm{CH}$ should be measured from the moment that the buds completely enter endodormancy (ED) or winter recess, until the moment in which they are completely liberated and enter an ecodormant state (EC) (Lang et al., 1987). These physiological states of the buds are not observed at first sight, being necessary to carry out experiments of forced budbreaking (Dennis, 2003) in order to know more deeply ED throughout the season, and thus define the precise moment at which the bud reaches the maximum ED depth and the moment at which it is released from this condition. Most research works do not consider these concerns, and the moment of beginning the counting of $\mathrm{CH}$ is determined in an arbitrary manner, and the end of the period is generally defined as the time in which bud-breaking begins, producing divergent results and considerable conceptual confusion (Allan, 2004). In relation to this, a very good review and discussion was recently published about the possible mechanisms involved in the induction and liberation from dormancy of the buds of deciduous trees (Arora et al., 2003).
The negative effect of high winter temperatures on accumulated winter-chill is of particular importance in the zones with sub-tropical climates (Byrne, 2005) and, consequently accumulated winter-chill in these regions measured as $\mathrm{CH}$, without considering the effect of high temperatures, can be a poor indicator of the chill effectively accumulated by the buds. To overcome this deficiency, other models have been developed in which the negative effect of high winter temperatures is considered in the calculation of accumulated winter-chill, which is no longer expressed as $\mathrm{CH}$ but rather as Chilling Units (CU) (Richardson et al., 1974; Allan and Burnett, 1995).

The Utah Model (Richardson et al., 1974) supposes that chill accumulation occurs within a temperature range of 2.5 and $12.5{ }^{\circ} \mathrm{C}$, outside of which, the accumulation is nil or negative. This model, although it gives good results in cool and cold temperate climates, yields a large quantity of negative chill values in sub-tropical climates and because of this its utilization and applicability have been limited (Dennis, 2003). A modification of this model consists of not considering the negative values of the Utah model, because of which it has been termed the model of Positive Chill Units (PCU) and its application in these sub-tropical zones has improved the results obtained (Linsley-Noakes et al., 1995).

Nevertheless, the model that has given better results in warm temperate and sub-tropical climates is the Dynamic Model (Fishman et al., 1987; Erez et al., 1988). This model also considers the effect of high temperatures, supposing that the cold is accumulated in the buds of deciduous fruits in an irreversible manner once a critical concentration of an intermediary is reached, depending on the intensity and duration of the temperature. In this way, these three models appear as the most adequate way to estimate accumulated chilling for buds in recess of deciduous fruit (Dennis, 2003).

Considering the advantages and limitation of each of these, in this work the Dynamic Model was applied with the objective of comparing the calculated accumulated chilling in relation to the models currently being used in the country, using the records of hourly temperatures in the autumns and winters of the years 2005 and 2006 in two climatically contrasting localities in Chile, as are the temperate valley of Santiago in the Metropolitan Region and the sub-tropical condition of Vicuña in the Coquimbo Region. 


\section{MATERIALS AND METHODS}

\section{Temperature data}

The temperature data used were the hourly records between March 15 and August 31 of the years 2005 and 2006, from the automatic meteorological stations located in the Regional Research Centers Intihuasi in Vicuña ( $30^{\circ} 02^{\prime}$ South; 643 m.a.s.l.) Coquimbo Region, and La Platina in Santiago (33 $34^{\circ}$ 'South; 625 m.a.s.l.) Metropolitan Region, of the Instituto de Investigaciones Agropecuarias (INIA).

\section{Models for calculating chill Chilling hours}

The chilling hours of the period were calculated counting the hours in which the temperature remained $\leq 7$ and $>0{ }^{\circ} \mathrm{C}$.

\section{Chill units (Utah)}

The Utah model of chill units (CU) defines a CU as the permanence of the buds for a period of 1 hour in a temperature range considered optimum $\left(2.5-12.5^{\circ} \mathrm{C}\right)$ to accumulate chill. Temperatures $<1.4{ }^{\circ} \mathrm{C}$ do not contribute to chill accumulation and are assigned a 0 value; temperatures between 1.5 and $2.4{ }^{\circ} \mathrm{C}$ contribute $0.5 \mathrm{CU}$; temperatures between 12.5 and $15.9^{\circ} \mathrm{C}$ also do not contribute to chill accumulation, while temperatures between 16 and $18{ }^{\circ} \mathrm{C}$ contribute negatively $-0.5 \mathrm{CU}$; and temperatures over $18{ }^{\circ} \mathrm{C}$ are assigned a value of $1 \mathrm{UF}$, that is, subtracting values from the chill units accumulated due to temperatures within the range of 1.5 and $12.5^{\circ} \mathrm{C}$ (Richardson et al., 1974).

The model of Positive Chill Units (PCU) is a modification of the Utah Model, which does not consider the negative values for the chill accumulation, and which is designed for situations where, because of the abundance of high winter temperatures (temperatures $>16^{\circ} \mathrm{C}$ ) the final values are negative (Linsley-Noakes et al., 1995).

\section{Dynamic Model}

The Dynamic Model was developed in Israel (Fishman et al., 1987), precisely to make corrections because of high winter temperatures that occur in the Jordan Valley (30-32 ${ }^{\circ}$ North lat.), and is based on the hypothesis that chill accumulation occurs in the form of portions or quantum of chill, according to a model that occurs in two stages, as shown in the following scheme:

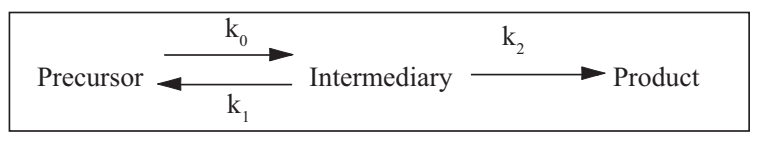

The first stage is a reversible process consisting of the formation and destruction of an intermediary based on a precursor. The formation of the intermediary depends exclusively on the temperature regime, and the constants of the velocity of formation $\left(\mathrm{k}_{0}\right)$ and destruction $\left(\mathrm{k}_{1}\right)$ of the intermediary are related to temperature according to the Arrhenius equation (France and Thornley, 1984),

$$
k=A \times e^{(-E / T)}
$$

where $\mathrm{T}$ is the absolute temperature expressed in Kelvin degrees $\left({ }^{\circ} \mathrm{K}\right), \mathrm{E}$ is the activation energy for the formation and destruction of the intermediary, and $\mathrm{A}$ is an independent coefficient of the temperature, which has the same dimensions as the constant of velocity (k). The model assumes that the whole effect of temperature on the concentration of the intermediary can be described using the parameters $\mathrm{E}_{0}, \mathrm{E}_{1}, \mathrm{~A}_{0}$ and $\mathrm{A}_{1}$ (Fishman et al., 1987). The model also assumes that because $\mathrm{E}_{1}$ participates in the destruction of the intermediary, which occurs at the highest temperatures, $\mathrm{E}_{1}>\mathrm{E}_{0}$, and as a consequence of this, the higher the temperature the lower is the concentration of the intermediary.

Once a certain critical concentration of the intermediary is reached, in a second stage the intermediary is transformed irreversibly into a product or a chill portion, and the concentration of the intermediary falls to zero and the dynamic curve exhibits a periodic behavior. The model incorporates a second adjustment to correct the effect of the low temperatures and assumes a critical temperature of 4 ${ }^{\circ} \mathrm{C}$, below which only a fraction of the intermediary is transformed into a product, thus beginning a new cycle with a concentration of the intermediary that is greater than zero. In this way the dynamic model is substantially differentiated from the other models in which chill units or chill portions (CP), once accumulated, cannot be annulled by high temperatures (Dennis, 2003).

This two-stage model for calculating winter chilling is currently being used by the meteorological services of Israel and South Africa, as well as some states in the southern United States (Zvi Zemel. 2006. Meteorological Service of Israel, Agrometeorological Section, Tel Aviv, Israel. Personal communication). 


\section{RESULTS}

\section{Simulation of the dynamic model}

The simulation of the dynamic model during a period of $100 \mathrm{~h}$ of constant temperatures of 3,6 and $14^{\circ} \mathrm{C}$ is shown in Figure 1 (A, B and C, respectively). At a constant temperature of $6{ }^{\circ} \mathrm{C}$ (Figure 1B), the model predicts that the critical concentration of the intermediary to transform itself into a product is reached after $28 \mathrm{~h}$, that all the intermediary is transformed into product, and that the concentration of the intermediary returns to zero at the beginning of each new cycle. After $100 \mathrm{~h}$ have passed three units of product or chilling portions (CP) have been accumulated.

At a temperature of $3{ }^{\circ} \mathrm{C}$ (Figure 1A), the model predicts that the critical concentration of the intermediary is reached at $30 \mathrm{~h}$, that only a fraction of

A

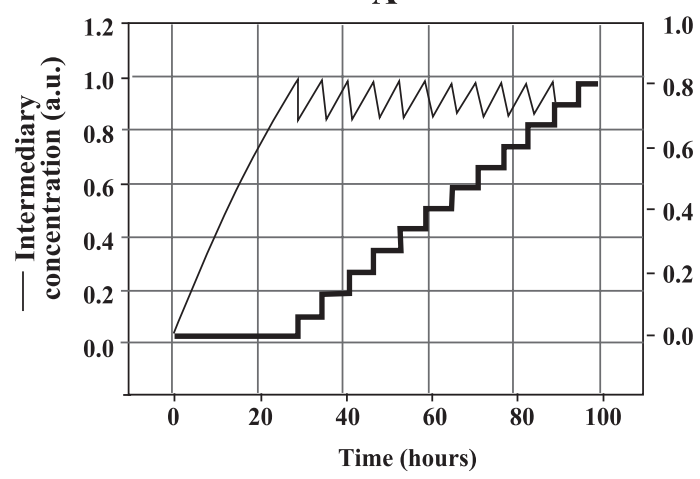

C

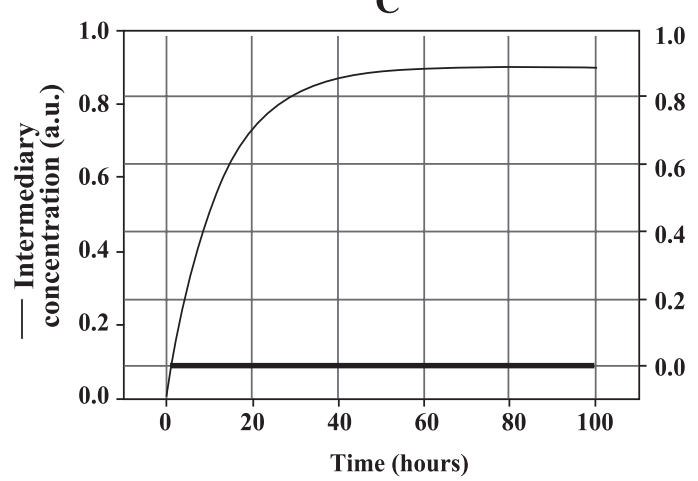

the intermediary is transformed into product after each cycle, and, consequently, the concentration of the intermediary is not zero at the beginning of each new cycle, and after $100 \mathrm{~h}$ has passed, $2 \mathrm{CP}$ are accumulated. The model indicates that accumulated chilling at a temperature of $3{ }^{\circ} \mathrm{C}$ is less efficient than at a temperature of $6{ }^{\circ} \mathrm{C}$. At a constant temperature of $14{ }^{\circ} \mathrm{C}$ the concentration of the intermediary never reaches the critical value, and consequently there is no accumulation of $\mathrm{CP}$, independently of the time passed (Figure 1C). The dynamic model also predicts that a cycle of high and low temperatures is more efficient in the accumulation of $\mathrm{CP}$ than a cycle of constant low temperatures. Thus, a cycle of $27 \mathrm{~h}$ with alternating temperatures of $2 \mathrm{~h}$ at $20^{\circ} \mathrm{C}, 1 \mathrm{~h}$ at 19,18 , 14,12 and $1{ }^{\circ} \mathrm{C}, 11 \mathrm{~h}$ at $10{ }^{\circ} \mathrm{C}, 5 \mathrm{~h}$ at $6^{\circ} \mathrm{C}$ and $3 \mathrm{~h}$ at $7{ }^{\circ} \mathrm{C}$, takes $80 \mathrm{~h}$ in accumulating $3 \mathrm{CP}$ (Figure 1D), while at a constant temperature of $6^{\circ} \mathrm{C}$, it takes $85 \mathrm{~h}$ (Figure 1B).
B

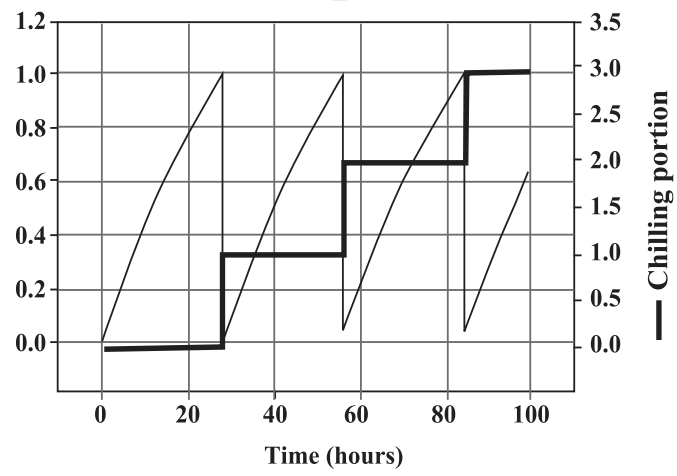

D

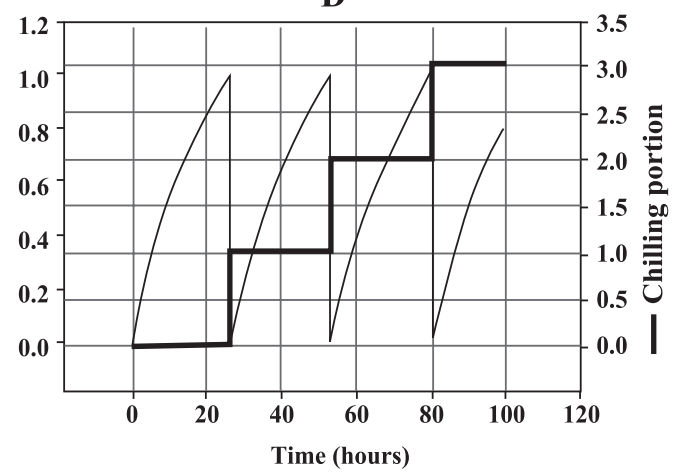

Figure 1. Dynamic model simulation for chill accumulation (chill portions, CP) at constant temperatures of $3{ }^{\circ} \mathrm{C}$ $(\mathrm{A}), 6^{\circ} \mathrm{C}(\mathrm{B})$ and $14^{\circ} \mathrm{C}(\mathrm{C})$, and alternate temperatures of $2 \mathrm{~h}$ at $20^{\circ} \mathrm{C} ; 1 \mathrm{~h}$ at $19,18,14,12$ and $11{ }^{\circ} \mathrm{C} ; 11 \mathrm{~h}$ at $10{ }^{\circ} \mathrm{C} ; 5 \mathrm{~h}$ at $6{ }^{\circ} \mathrm{C}$ and $3 \mathrm{~h}$ at $7{ }^{\circ} \mathrm{C}$ (D) over a period of $100 \mathrm{~h}$.

a.u.= arbitrary units 
Calculation of accumulated winter-chill in the Coquimbo and Metropolitan Regions using the dynamic model

The application of the dynamic model to the hourly temperature regimes of both regions during the period of March-August of 2006 is presented in Figure 2. By the end of the autumn-winter seasons in Santiago, 73 chill portions had been accumulated, which was considerable more than in Vicuña, where only 30 chill portions were produced. The results also indicated that the accumulation of chill portions in Vicuña began later (May 3) than in Santiago, where chilling began to be accumulated prior to March 30. In both regions the period of greatest accumulation occurred between mid-July and mid-August, that is, during the winter months.

Comparison of accumulated winter-chill in the Coquimbo and Metropolitan Regions for the years 2005 and 2006 using the different calculation models

The comparison of winter-chill between the two regions calculated as chilling hours $(\mathrm{CH})$, as Positive Chill Units (PCU) and as chill portions (CP) for the
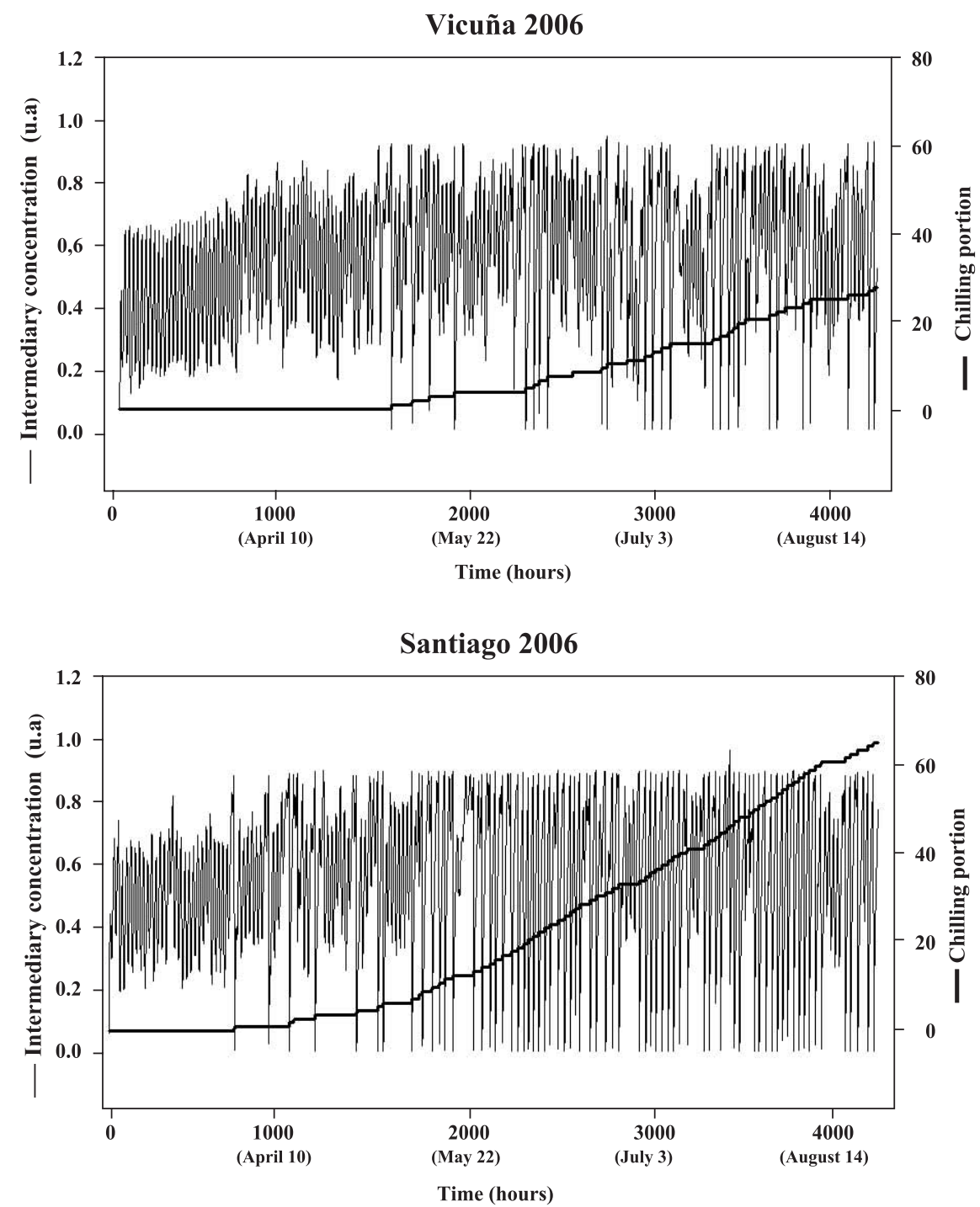

Figure 2. Variations in intermediate concentration and accumulated chilling portions as a function of temperatures per hour in Vicuña (Region of Coquimbo) and Santiago (Metropolitan Region), between March 1 and August 31, 2006. a.u.= arbitrary units 
- Vicuña Región de Coquimbo

- S Santiago Región Metropolitana

2005
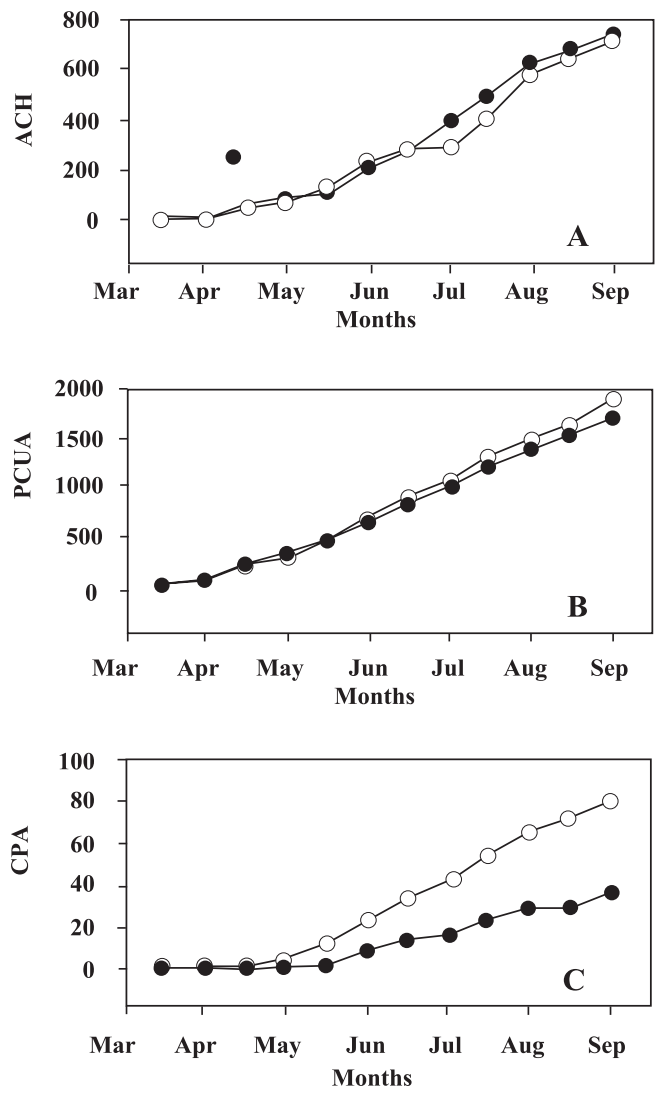

2006
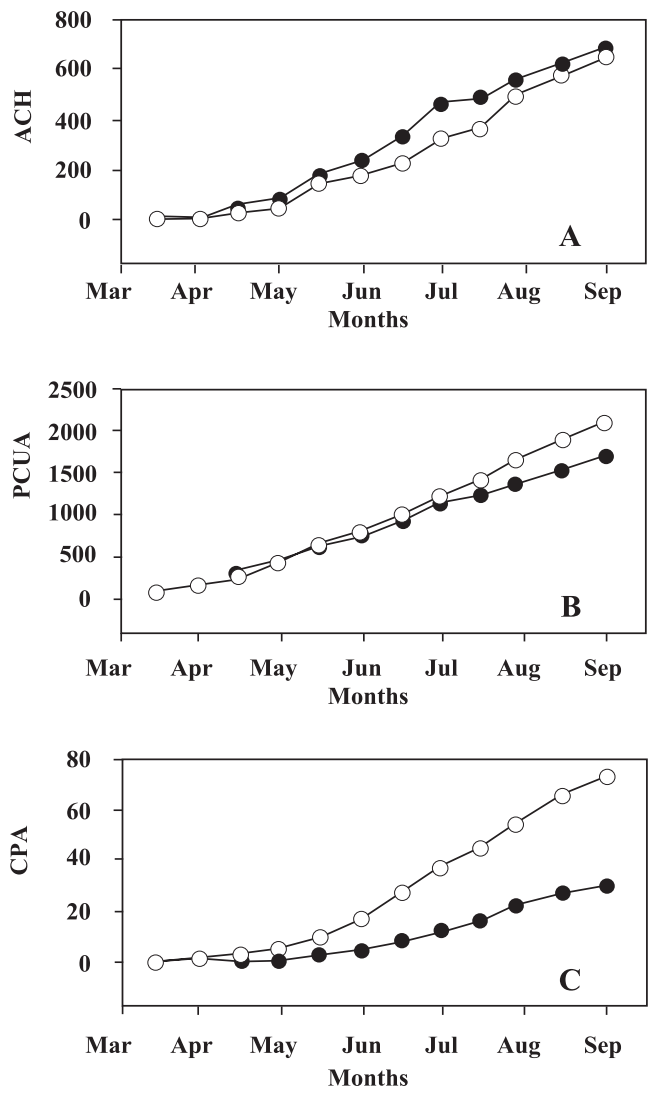

Figure 3. Accumulated chilling in Santiago (Metropolitan Region, RM) and Vicuña (Region of Coquimbo) between 1 March and 31 August of the years 2005 and 2006 according to (A) models of Chilling Hours (ACH), (B) Positive Chilling Units (PCUA) and (C) Dynamic Model's Chilling Portions (CPA).

autumn-winter seasons of the years 2005 and 2006 are presented in Figure 3. During the two seasons analyzed, the $\mathrm{CH}$ model does not discriminate between the two regions, finding that the accumulated $\mathrm{CH}$ in Santiago for the years 2005 and 2006 were 708 and $642 \mathrm{CH}$, respectively, while for Vicuña they were 744 and $673 \mathrm{CH}$.

The Utah Model showed negative values for the months of March, April and May, for both localities, and as well showed negative values for the end of June in Vicuña. This high proportion of negative values of accumulated winter-chill, which particularly occurs when the calculations are made with temperatures-hours, confirms the limitations of this model for sub-tropical latitudes. Calculation of chill employing the PCU model indicated a greater accumulation of chilling in Santiago (1880 and 2086 PCU) than in Vicuña (1709 and 1692 PCU) for the two years analyzed. Nevertheless, the difference between the two regions is small in magnitude and is only evident after mid-June, given that prior to this date accumulated chilling was practically the same in the two regions. The dynamic model of $\mathrm{CP}$ also indicated a greater accumulation of chill in Santiago, but with the difference from the preceding model that the contrasts are reflected from the beginning of autumn (April) being repeatedly more marked throughout the season. At the end of the period, and in both years, the accumulated CP in Santiago was twice the number accumulated in the Coquimbo Region. 


\section{DISCUSSION}

The $\mathrm{CH}$ model widely used in Chile to measure winter chill indicated that the quantity of accumulated chilling during the autumn-winter seasons of the years 2005 and 2006 were practically the same for the localities of Vicuña and Santiago. As well, experiments carried out with cv. Thompson Seedless vines in these same years and in the same locations of this study concluded that the accumulated $\mathrm{CH}$ during the period from the complete development of ED in the buds until its completion are equal in the two climatic zones (Pérez et al., 2007). Nevertheless, it is known that grapevines in the Metropolitan Region do not present problem of deficit of chilling and buds burst homogeneously at the beginning of spring, while the symptoms characteristic of deficit of winter chilling, such as uneven and erratic bud-break, are present in the Coquimbo Region.

It has recently been indicated that the release from ED of grapevine buds in the central Chile occurs at the end of winter (August) (Pérez et al., 2007), and as the accumulated $\mathrm{CH}$ during the interval that the ED lasted was equal in the two regions, the differences in bud-break rates cannot be justified by a variation in the measuring times of $\mathrm{CH}$. It is contradictory to observe that bud-breaking of Thompson Seedless vines in the Coquimbo Region is erratic and uneven, and that the model currently used in Chile to quantify winter-chill indicates that the winter-chill accumulated in Vicuña is equal to that accumulated in Santiago, where buds do burst normally. This apparent contradiction is due to the method of measuring winter chilling. The $\mathrm{CH}$ model only considers temperatures below $7{ }^{\circ} \mathrm{C}$ in the quantification of accumulated winter-chill and does not consider the possible effect that high winter temperatures can have on accumulated winter-chill.

Upon applying the Utah model (Richardson et al., 1974), which considers that high temperatures have a negative effect on accumulated chilling, negative values were obtained during the autumns in both regions, especially in Vicuña where the high temperatures offset the scarce low winter temperatures, similar to what has been reported in other countries, such as Israel (Fishman et al., 1987), South Africa (Allan et al., 1993; Allan, 2004), and
Mexico (del Real-Laborde, 1989). A modification of this model, in which the negative values are omitted, has been used successfully to describe a sub-tropical condition in South Africa (Allan et al., 1993). Nevertheless, its predictive applicability and practical significance remains to be demonstrated, given that the exclusion of negative values opposes to the basic principle of the model and that high temperatures cancel out the effect of low temperatures (Dennis, 2003). In this case, upon applying the PCU model to the temperature regimes by hour in the Metropolitan Region and the Coquimbo Region, it is observed that this model effectively discriminated between the quantity of accumulated chill in the two regions, showing a greater number of PCU in more temperate latitudes. Nevertheless, the differences between the two localities are still small in magnitude and are only evident beginning the month of July, demonstrating in this way the limitations of the model to describe zones where the predomination of high winter temperatures negatively affects the onset and uniformity of bud-breaking in deciduous trees.

Upon applying the Dynamic Model developed in Israel, the two localities are clearly differentiated, reaching more than double of $\mathrm{CP}$ in the Metropolitan Region than in the Coquimbo Region, besides they were observed from the beginning of the autumn season (April). Consequently, the results provided by the $\mathrm{CP}$ model would explain better the differences of latent buds breaking between the two regions, establishing a notable contrast in the accumulated chilling during the winter between a temperate area like Santiago and another with high daily winter temperatures, like Vicuña. It is interesting to note that the results obtained by applying the CP model not only serve to determine with precision the chill accumulation for a sub-tropical condition, but also allows for calculating with exactitude accumulated chilling in latitudes with temperate winters. The versatility of the dynamic model makes it particularly interesting for determining with high precision those geographic zones with micro-climates, as are found throughout the country. Notwithstanding, it is important to carry out field tests under local conditions that allow for relating these models to bud-break data from different species of deciduous trees, and thus determine the utility of this dynamic model for evaluating accumulated winter chill. 


\section{CONCLUSIONS}

The $\mathrm{CH}$ model currently used in our country by agrometeorological services as an indicator of accumulated winter-chill is inadequate for sub-tropical climatic zones. By not considering the impact of high winter temperatures and daily temperature cycles on accumulated winter-chill, the model does not allow for discriminating between a temperate climate, such as that of Santiago in the Metropolitan Region, and a sub-tropical climate, such as that of Vicuña in the Coquimbo Region. Consequently, the replacement of the $\mathrm{CH}$ model by the dynamic model as a means to calculate accumulated winter-chill in regions of Chile should be evaluated, with additional research covering all the climatic zones where species having winter chill requirements are cultivated.

\section{ACKNOWLEDGEMENTS}

We thank FONDECYT for the funding of project 1050285, Dr. Zvi Zemel of the Meteorological Service of Israel for permitting us to use the Dynamic Model computer program, and Mrs. Carmen Jopia and Lucía Hernández of INIA for facilitating the temperature data from Vicuña and Santiago, respectively.

\section{R E S U M E N}

Utilización del modelo dinámico para evaluar el frío invernal en una localidad de clima templado y otra subtropical de Chile. Francisco J. Pérez ${ }^{1 *}$, Juan Ormeño N. ${ }^{2 *}$, Bryan Reynaert ${ }^{2}$, y Sebastián Rubio $^{1}$. Se evaluó el frío invernal acumulado en Santiago (3334' lat. Sur; 625 m.s.n.m.; Región Metropolitana) y Vicuña $\left(30^{\circ} 02^{\prime}\right.$ lat. Sur; 643 m.s.n.m.; Región de Coquimbo) durante las temporadas 2005 y 2006 aplicando tres diferentes modelos. El modelo de horas-frío $(\mathrm{CH})$, actualmente empleado como indicador agroclimático en Chile, resultó de poca utilidad para contrastar efectivamente la condición subtropical de Vicuña con la condición templada de Santiago. Al utilizar el modelo de Utah se obtuvieron valores negativos de marzo a mayo e incluso hasta el mes de junio en Vicuña, ya que, precisamente, con este modelo el efecto del frío es anulado por las altas temperaturas. Sin embargo, una modificación de este modelo, denominado Unidades de Frío Positivas (UPF), en que los valores negativos se omiten, mostró diferencias en el frío acumulado entre ambas regiones, pero las diferencias fueron pequeñas y se expresaron sólo a partir del mes de julio en adelante. La aplicación del Modelo Dinámico, que considera que el frío se acumula en forma irreversible, como quantum o Porciones de Frío (PF), mostró que el frío invernal acumulado en la Región Metropolitana es el doble que en la Región de Coquimbo, y que las diferencias se expresan desde los inicios del otoño, haciéndolo así particularmente aplicable para zonas subtropicales. En este trabajo se discuten las ventajas del modelo dinámico por sobre los otros modelos utilizados.

Palabras clave: frío invernal acumulado, dormancia yemas, modelo dinámico.

\section{LITERATURE CITED}

Allan, P. 2004. Winter chilling in areas with mild winters. Its measurement and supplementation. Acta Hort. 662:47-52.

Allan, P., and M.J. Burnett. 1995. Peach production in an area with low winter chilling. J. S. Afr. Soc. Hortic. Sci. 5:15-18.

Allan, P., G. Ruffus, G.W. Matthee, and G.C. LinsleyStokes. 1995. Winter chill models in a mild subtropical area and effects of constant $6{ }^{\circ} \mathrm{C}$ chilling on peach budbreak. Acta Hort. 409:9-17.
Arora, R., L.J. Rowland, and K. Tanino. 2003. Induction and release of bud dormancy in woody perennials: A science comes of age. HortScience 38:911-921.

Boonprakob, U., and D.H. Byrne. 2005. Breeding lowchill stone fruit in Thailand. p. 39-42. ACIAT Technical Report $\mathrm{N}^{\circ}$ 61. In George, $\mathrm{A}$ and $\mathrm{U}$. Boonprakoh (eds.). Production technologies for lowchill temperate fruits. Reports from the $2^{\text {nd }}$ 
International Workshop, Chiang Mai, Thailand. 1923 April 2004. Australian Centre for International Agricultural Research (ACIAR), Canberra, Australia.

Byrne, D.H. 2005. Trends and progress of low chill stone fruit breeding. p. 5-12. ACIAT Technical Report $\mathrm{N}^{\mathrm{o}}$ 61. In George, A., and U. Boonprakoh (eds.). Production technologies for low-chill temperate fruits. Reports from the $2^{\text {nd }}$ International Workshop, Chiang Mai, Thailand. 19-23 April 2004. Australian Centre for International Agricultural Research (ACIAR), Canberra, Australia.

Del Real-Laborde, J.I. 1989. An apple test model for mild winter conditions. 72 p. Ph.D. Diss. Utah State Univ., Logan, Utah, USA (Abstract).

Dennis, F.G. Jr. 2003. Problems in standardizing methods for evaluating the chilling requirements for the breaking of dormancy in buds of woody plants. HortScience 38:347-350.

Erez, A., S. Fishman, Z. Gat, and G.A. Couvillon. 1988. Evaluation of winter climate for breaking bud rest using the dynamic model. Acta Hort. 232:76-89.

Fishman, S., A. Erez, and G.A. Couvillon. 1987. The temperature dependence of dormancy breaking in plants: mathematical analysis of a two step model involving cooperative transition. J. Theor. Biol. 124:473-483.

France, J., and J.H.M. Thornley. 1984. Mathematical models in agriculture. Temperate dependence of development and the Arrhenius equation. Butterworths, London, UK.

Lang, G.A. 1987. Dormancy: A new universal terminology. HortScience 22:817-820.

Lang, G.A., J.D. Early, R.D. Darnell, and G.C. Martin. 1987. Endo-, para- and ecodormancy: Physiological terminology and classification for dormancy research. HortScience 22:371-377.

Linsley-Noakes, G., M. Louw, and P. Allan. 1995. Estimating daily positive Utah chill units using daily maximum and minimum temperatures. J. S. Afr. Soc. Hortic. Sci. 5:19-22.

Lyon S., M., S. Poller R., y M. Rodríguez-Cano S. 1989. Evolución del letargo de yemas en seis especies frutales en relación al frío y tratamiento con tiourea o cianamida. 82 p. Tesis de Ing. Agrónomo. Pontificia Universidad Católica de Chile, Facultad de Agronomía, Santiago, Chile.
Pérez, F.J., S. Rubio, and J. Ormeño-Núñez. 2007. Is erratic bud-break in grapevines grown in warm-winter areas related to disturbances in mitochondria respiratory capacity and oxidative metabolism? Funct. Plant Biol. 34:624-632.

Powell, A.A. 1997. The effect of Dormex on replacing lack of chilling in kiwifruit. Auburn University. Available at http:/www.aces.edu.department/peaches/ kiwidormex.html (Accessed 18 October 2006).

Reginato M, G., C. Pinilla D., y J. L. Camus C. 1994. Efecto de la aplicación de cianamida hidrogenada más aceite mineral en Vitis vinifera L. cv. Thompson Seedless. Agric. Téc. (Chile) 54:192-198.

Richardson, E.A., S.D. Seeley, and D.R. Walker. 1974. A model for estimating the completion of rest for 'Redhaven' and 'Elberta' peach trees. HortScience 9:331-332.

Rojas T., W., C. Zoccola F., y A. Osorio U. 1999. Establecimiento de un huerto frutal, factores agronómicos a considerar. Serie Intihuasi N $\mathrm{N}^{\mathrm{0}} 21.8 \mathrm{p}$. Instituto de Investigaciones Agropecuarias, Centro Regional de Investigación Intihuasi, La Serena, Chile.

Sapiaín, R., R. Callejas, G. Reginato, y V. García de Cortázar. 2005. Determinación de requerimientos de frío invernal y térmico para el desarrollo de la vid "Sultanina". p. 85. 56 Congreso Agronómico de Chile, Chillán. 11-14 octubre de 2005. Libro de Resúmenes. INIA y Universidad de Concepción, Chillán, Chile.

Saure, M.C. 1985. Dormancy release in deciduous fruit trees. Hort. Rev. 7:239-299.

Tao, R. 2004. Studies of the gene expression of dormant buds of Japanese apricot (Prunus mume). p. 48-53. ACIAT Technical Report $N^{\circ}$ 61. In George, A and U. Boonprakoh (eds.). Production technologies for lowchill temperate fruits. Reports from the $2^{\text {nd }}$ International Workshop, Chiang Mai, Thailand. 1923 April 2004. Australian Centre for International Agricultural Research (ACIAR), Canberra, Australia. Weinberger, J.H. 1950. Chilling requirements of peach varieties. Proc. Am. Soc. Hortic. Sci. 56:122-28. 